\title{
O preço do afeto: a responsabilidade civil pelo abandono afetivo
}

\section{POR FRANCISCO CARVALHO CORREA $(*)(* *)$}

\author{
Sumario: I. Introdução.- II. Breve histórico do direito de familia.- \\ III. A família em face do código civil Brasileiro.- IV. Da responsabili- \\ dade civil e sua.- V. Da responsabilidade civil pelo abandono afetivo.- \\ VI. Conclusão.- VII. Referência.
}

Resumo: o tema deste estudo enseja grandes discussões. Trata-se da responsabilidade civil pelo abandono afetivo, e consequentemente a possibilidade de reparação dos danos causados ao filho abandonado. Com base nos princípios da dignidade da pessoa humana, da paternidade e maternidade responsável, da proteção integral da criança e do adolescente, bem como do dever de cuidado, convivência e proteção dos pais para com os filhos, foi traçado o objetivo do presente trabalho, que visa demonstrar que os cuidados com um filho não se referem apenas ao sustento materialmente, mas também ao afeto, amparo moral, psicológico e social, fundamentais para a formação e desenvolvimento sadio de uma criança. A grande discussão é se o abandono afetivo do genitor configura ou não um ato ilícito, pressuposto para aplicação da responsabilidade civil. Apesar da divergência, gradativamente estão surgindo decisões favoráveis à responsabilização pelo abandono afetivo, confirmando que cuidado não se trata apenas de faculdade, mas um dever imposto pela própria Constituição Federal Brasileira.

Palavras chaves: afeto - dignidade da pessoa humana - responsabilidade civil

\section{The price of affection: the civil responsibility for the abandoment affective}

Abstract: the subject of this study provokes great discussions. It is the civil responsibility for the abandonment affective, and consequently the possibility of reparation of the damages caused to the abandoned son. Based on the principles of human

(*) La realización de este trabajo contó con la colaboración de Thainá Silva Andrade Oliveira.

(**) Doutor em Ciências Jurídicas e Sociais pela Universidade Nacional La Plata, sendo reconhecido como Doutor em Direito pela Universidade Federal de Minas Gerais-UFMG. Possui graduação em Direito pela Universidade Iguaçu, especialização em Dir. Civil e Proc. Civil pela Universidade Veiga de Almeida e em Formação em Ensino a Distância, pela Universidade Paulista. Prof. Universitário, Faminas, Campus Muriaé, Muriaé, Minas Gerais, Brasil e Diretor Jurídico da Câmara Municipal de Muriaé. 
dignity, responsible paternity and maternity, the integral protection of children and adolescents, as well as the duty of care, coexistence and protection of parents with their children, the objective of this work was drawn, Which aims to demonstrate that caring for a child refers not only to materially, but also to affection, moral, psychological and social support, fundamental for the healthy formation and development of a child. The great discussion is whether or not the affective abandonment of the parent constitutes an unlawful act, presupposed for the application of civil responsibility. Despite the divergence, decisions are gradually emerging that favor affection abandonment, confirming that care is not only about faculty, but a duty imposed by the Brazilian Federal Constitution itself.

Keywords: affective - dignity of human person - civil responsibility

\section{Introdução}

O presente estudo tem por escopo analisar a possibilidade de indenização e aplicação da responsabilidade civil na hipótese de abandono afetivo por um dos pais. Esse tema tem entendimentos divergentes e controvertidos dentro dos tribunais pátrios, dos quais alguns serão trazidos à baila.

Com o advento da Constituição de 1988 e a valorização da pessoa humana, diversos institutos tiveram de ser criados ou alterados, a fim de que fosse compreendido que não é possível pensar em família sem pensar em carinho, respeito, dignidade, cidadania e inclusão. O fundamento da família moderna é o afeto, o qual por sua vez tornou-se um valor jurídico, elevado à categoria de princípio, e que tem sido suporte para a possibilidade de indenização por abandono afetivo no âmbito familiar.

Cabe destacar que o progresso humano só será possível se nele estiverem presentes os aspectos morais, intelectuais, afetivos, psíquicos e materiais. A formação da personalidade de um jovem está intimamente ligada a sua relação com os pais, que por si, possuem o dever de cuidado para com estes. O que se discute é a possibilidade de indenização, ressarcimento dos danos causados na hipótese desse dever de cuidado ser descumprido. Embora o dano psicológico seja uma das consequências da falta de afetividade, o sentimento de desprezo também contribui para a construção de traumas difíceis de serem reparados.

A discussão paira sobre a existência ou não de ato ilícito, na conduta do genitor que abandona afetivamente o filho, seja por ação ou omissão voluntária, negligência ou imprudência, e se o abandono viola um direito, causando danos, ainda que exclusivamente moral. 
Quando a escolha é pelo planejamento familiar, e o trabalho feito com base na maternidade e paternidade responsáveis, os filhos são fecundos no amor, e buscarão neste, a energia e inspiração para viverem.

\section{Breve histórico do direito de família}

Não há na história dos povos antigos o surgimento de uma sociedade que não tenha como base a família. O modelo de família brasileiro é originário da família Romana, que por sua vez, sofreu grande influência do modelo grego.

\section{II.1. A família no direito Romano}

Ao longo dos anos, muito se modificou no instituto da família, com a criação de novos modelos, novos conceitos e características. A sociedade cada vez mais globalizada pelos meios de comunicação identifica modalidades de família bastante distintas das civilizações passadas, mas que muito influenciaram para a sua compreensão.

A esse respeito, leciona o doutrinador Sílvio de Salvo Venosa (2012, p. 19)

No curso das primeiras civilizações de importância, tais como a assíria, hindu, egípcia, grega e romana, o conceito de família foi de uma entidade ampla e hierarquizada, retraindo-se hoje, fundamentalmente, para o âmbito quase exclusivo de pais e filhos menores, que vivem no mesmo lar.

Da família romana e grega, pode-se destacar a existência do pater, ocupada pela figura masculina. $O$ termo latino compreendia o pai de família, o que detinha o pátrio poder. Tal posição era exercida pelo ascendente comum vivo mais velho, que desemprenhava as funções juiz, chefe político, sacerdote e, além disso, dirigia o culto doméstico dos deuses. Portanto, encontravam-se sob o seu poder os filhos, a esposa, os servos e os escravos, independia assim, do fator consanguíneo. Possuía sobre os filhos o direito de vida e de morte, podia castigá-los, vendê-los, e até mesmo matá-los quando bem entendesse. A mulher era totalmente submissa à autoridade marital e podia ser repudiada por ato unilateral do marido.

A família romana era constituída a partir do casamento, predominando desde sempre a desigualdade entre os seus membros e a supremacia dos interesses do pater familias. No casamento era fundamental a presença do affectio, não só no momento da sua constituição, mas enquanto este perdurasse, e sua ausência era motivo para a dissolução do vínculo. 


\section{II.2. A família no direito canônico}

Por volta do século IV, com o Imperador Constantino, passou a vigorar uma concepção de família cristã no direito romano, restringindo-se a autoridade do pater e outorgando maior autonomia aos filhos e as mulheres.

A família passa a reger-se pelo direito canônico, que de início surgiu com o objetivo de decidir sobre assuntos não regulados pelo direito. Sobre tais regras, apenas o casamento religioso era considerado válido, sendo tido como algo sagrado e que não poderia ser dissolvido, mesmo que houvesse a vontade de ambas as partes, por entender-se que a união era realizada por Deus.

A única função do casamento era a procriação e criação dos filhos, não se levava em consideração a felicidade dos nubentes, que possuíam o dever de respeitar todos os princípios e normas estipuladas pelo direito canônico, e aquele que viesse a desobedecê-lo, sofreria punições rigorosas.

Conforme acentua Sílvio de Salvo Venosa (2012, p. 23)

O direito de família canônico era constituído por normas imperativas, inspiradas na vontade de Deus ou da vontade do monarca. Era constituído por cânones, regras de convivência impostas aos membros da família e sancionadas com penalidade rigorosas. O casamento, segundo os cânones, era a pedra fundamental, ordenado e comandado pelo marido.

O direito canônico perdurou por quase quatrocentos anos e muito influenciou no direito de família brasileiro, como consequência principalmente da colonização lusa. As ordenações Filipinas foram uma das principais fontes do referido direito, que atingiu o direito pátrio.

Pode-se observar que há poucos anos atrás ainda eram obedecidas regras rígidas, mas em razão da evolução da sociedade, o direito de família passou a seguir rumos próprios, deixando-as para trás.

\section{II.3. A família na Constituição Brasileira}

As Constituições são elaboradas em contexto com o momento histórico e social vivenciado pela sociedade, e assim, no decorrer dos tempos, regras e normas foram sendo introduzidas nas constituições brasileiras no que concerne ao direito de família. 
Com a promulgação da Constituição da República Federativa do Brasil no ano de 1988, a família patriarcal, até então adotada como modelo pela legislação brasileira, desde a Colônia, o Império e boa parte do século XX, sofre mudança brutal, sendo levada a um estado de colapso.

Nasceu a possibilidade de a família ter origem matrimonial ou não, atribuiu-se mais direitos às mulheres e aos filhos, privilegiando a dignidade da pessoa humana e valorizando a família socioafetiva. O direito de família ganhou tutela Constitucional e integrou como seus fundamentos, a solidariedade, o respeito aos membros da entidade familiar, o consenso, além de diversos outros estampados nos artigos 226 a 230 da Constituição de 1988.

Com fundamento nos princípios da dignidade da pessoa humana e da paternidade responsável, o legislador instituiu o planejamento familiar, afirmando ser este de livre decisão do casal, competindo ao Estado propiciar recursos educacionais e científicos para o exercício desse direito, vedada qualquer forma coercitiva por parte de instituições oficiais ou privadas (Artigo; Constituição, 1988, p. 226, $\left.\$ 7^{\circ}\right)$.

Assinala, a propósito, Carlos Roberto Gonçalves (2016, p. 33), que a Constituição de 1988 absorve essa transformação a partir de três eixos: O primeiro situa-se no artigo 226, quando afirma que a entidade familiar é plural e não mais singular, tendo várias formas de Constituição. O segundo eixo encontra-se no $\$ 6^{\circ}$ do artigo 227 , sendo a alteração do sistema de filiação, de sorte a proibir designações discriminatórias decorrentes do fato de ter a concepção, ocorrido dentro ou fora do casamento, e, por fim, o terceiro eixo consagra-se nos artigos $5^{\circ}$, inciso I, e 226 , $\S 5^{\circ}$, ao reconhecer o princípio da igualdade entre homens e mulheres, derrogando mais de uma centena de artigos do Código Civil de 1916.

De forma paradigmática, a constituição Brasileira de 1988 legitimou a união estável, oferecendo maiores possibilidades para o casamento, reconheceu a família monoparental, a isonomia entre o homem e a mulher quanto aos direitos e deveres referentes à sociedade conjugal, a dissolução do casamento independente de culpa, a igualdade jurídica de todos os filhos, dentre diversos outros que fazem do atual Direito de família Brasileiro, um modelo para outras Constituições.

\section{A família em face do código civil Brasileiro}

Diante da natural mudança nos costumes, cumulado com o advento da Constituição Federal de 1988, surgiu a necessidade de modificação da lei civil brasileira, que era a mesma desde 1916, e já não atendia aos anseios da sociedade contemporânea. O que era admitido anteriormente pela sociedade, como a ilegitimidade dos filhos concebidos fora do casamento, passou a ser repudiado. 
Apesar da demora na tramitação do projeto no Congresso Nacional, em 10 de janeiro de 2002 foi publicada a Lei no 10.406 que revogou o Código Civil de 1916. A família regulada pelo Código Civil de 2002 passou a enaltecer o convívio entre os seus membros e projetar um lugar em que fosse possível a existência de sentimentos, esperanças e valores, possibilitando a cada um, a realização de seu propósito pessoal de felicidade.

O aludido Código estabeleceu um título para reger o direito pessoal, e outro para a disciplina do direito patrimonial, com o reconhecimento de novos núcleos de relações de afeto. A família deixou de ser compreendida apenas como instituição jurídica sedimentada no casamento para adquirir um caráter de diversidade, motivado pela incessante busca por afeto e felicidade, a fim de se alcançar a promoção da personalidade humana. Assim, abriu-se espaço para a filiação baseada na convivência e no afeto e não só àquela de natureza consanguínea.

\section{III.1. Poder familiar}

O poder familiar consiste em direitos e deveres pertencentes aos pais, no que tange aos bens e à pessoa dos filhos, com a finalidade precípua de protegê-los até a maioridade ou emancipação. Segundo Carlos Roberto Gonçalves (2016, p. 408) “(...) é o conjunto de direitos e deveres atribuídos aos pais, no tocante à pessoa e aos bens dos filhos menores". A expressão surgiu com o intuito de substituir o até então denominado pátrio poder, exercido apenas pelo pai na ultrapassada sociedade patriarcal.

Em razão do princípio da isonomia introduzido na Constituição Federal de 1988, homens e mulheres passaram a possuir direitos e deveres idênticos na sociedade conjugal, portanto, compete a ambos o exercício do poder familiar, em igualdade de condições.

Depreende-se da leitura do artigo 226, §5º da Constituição Federal de 1988 "Os direitos e deveres referentes à sociedade conjugal são exercidos igualmente pelo homem e pela mulher".

Da mesma forma, indica o artigo 1.631 do Código Civil, "Durante o casamento e a união estável, compete o poder familiar aos pais, na falta ou impedimento de um deles, o outro o exercerá com exclusividade".

Por fim, o artigo 21 do Estatuto da Criança e do Adolescente preceitua:

Artigo. 21: O poder familiar será exercido, em igualdade de condições, pelo pai e pala mãe, na forma do que dispuser a legislação civil, asse- 
gurando a qualquer deles o direito de, em caso de discordância, recorrer à autoridade judiciária competente para a solução da divergência.

Possui característica de um múnus público, ou encargo, impondo antes deveres do que direitos. Tal instituto é irrenunciável, inalienável, indelegável e imprescritível, não podendo ser transferido pelos pais a terceiros, exceto na hipótese de adoção, em que ocorre a destituição do poder familiar. Sua perda só será verificada em casos excepcionais expressos na legislação.

Observa-se uma intervenção do Estado no âmbito do direito de família, objetivando conceder-lhes maior proteção e propiciar melhores condições de vida às novas gerações.

De acordo com o artigo 1.634 do Código Civil de 2002, os direitos e deveres dos pais para com os filhos consistem:

Artigo 1.634: Compete a ambos os pais, qualquer que seja a sua situação conjugal, o pleno exercício do poder familiar, que consiste em, quanto aos filhos: I - dirigir-lhes a criação e a educação; II - exercer a guarda unilateral ou compartilhada nos termos do art. 1.584; III conceder-lhes ou negar-lhes consentimento para casarem; IV - conceder-lhes ou negar-lhes consentimento para viajarem ao exterior; $\mathrm{V}$ - conceder-lhes ou negar-lhes consentimento para mudarem sua residência permanente para outro Município; VI - nomear-lhes tutor por testamento ou documento autêntico, se o outro dos pais não lhe sobreviver, ou o sobrevivo não puder exercer o poder familiar; VII - representá-los judicial e extrajudicialmente até os 16 (dezesseis) anos, nos atos da vida civil, e assisti-los, após essa idade, nos atos em que forem partes, suprindo-lhes o consentimento; VIII - reclamá-los de quem ilegalmente os detenha; IX - exigir que lhes prestem obediência, respeito e os serviços próprios de sua idade e condição.

Destarte, o modo como tais obrigações serão exercidas irá determinar a personalidade de cada um dos filhos.

Quanto aos filhos não reconhecidos pelo pai, caberá à mãe o exercício exclusivo do poder familiar, e no caso de ausência ou incapacidade de ambos os pais, nomear-se-á um tutor ao infante, nos termos do artigo 1.633 do Código Civil.

Ainda de acordo com o Código Civil (artigo 1.635), a extinção do poder familiar só ocorrerá na hipótese de emancipação, maioridade, morte dos pais ou dos filhos, pela adoção, e por decisão judicial expressa em casos como abandono, castigo 
imoderado, pratica de atos contrários à moral e aos bons costumes ou reincidência em causas de suspensão do poder familiar.

O poder familiar poderá ser suspenso de forma temporária quando ocorrer o abuso de autoridade por parte dos pais, pelo exercício de algum ato que prejudique os bens dos filhos, ou quando condenados por sentença irrecorrível, em detrimento de crime cuja pena seja superior a dois anos. A suspensão deverá ser analisada pelo juiz sempre em observância aos interesses e segurança do menor, devendo perdurar até que se interrompa a causa que lhe deu motivo.

O objetivo de se atribuir aos pais o poder familiar é propiciar aos filhos o amor, o carinho, o diálogo, de forma que não se resumam em um conjunto de direitos e deveres separados em pessoais e patrimoniais, mas uma união de afeto, paz e harmonia.

\section{III.2. Princípios do Direito de Família}

Na medida em que os costumes da sociedade foram se modificando, os preceitos que a orientam também tiveram de ser alterados. Para preservar as famílias e seus valores culturais, bem como para atender às necessidades da prole, o direito de família, atualmente, é regido por diversos princípios, os quais serão agora analisados.

O princípio da igualdade jurídica dos cônjuges e dos companheiros, no que toca aos seus direitos e deveres, está definido no artigo 226, §5 da Constituição Federal. $\mathrm{O}$ mencionado dispositivo pôs fim ao poder marital e à restrição da mulher apenas aos cuidados com a família, instituindo um sistema em que as decisões no âmbito familiar devem ser tomadas em conjunto por ambos os cônjuges ou companheiros, como por exemplo, quanto a administração dos bem comuns, o domicílio, a manutenção da família, devendo as divergências serem levadas até o juiz. Há uma equidade de papéis, de forma que a responsabilidade pela sociedade conjugal passa a ser dividida igualmente entre o casal.

Consubstanciado no artigo 227, $\$ 6^{\circ}$ da Constituição Federal, o princípio da igualdade jurídica de todos os filhos, consagra que não há distinção entre filiação legítima, natural ou adotiva, quanto ao nome, poder familiar, alimentos e sucessão, autorizando, em qualquer momento, o reconhecimento de filhos havidos fora do matrimônio. Ademais, o aludido princípio proíbe que seja incluída na certidão de nascimento, qualquer menção à filiação ilegítima, e proíbe designações discriminatórias relacionadas à filiação.

O artigo 226, $\S 7^{\circ}$ da Constituição Federal tipifica o princípio da paternidade e maternidade responsável e do planejamento familiar, sendo de livre decisão de 
ambos os genitores, cônjuges ou conviventes, o dever de propiciar aos filhos o bem estar físico, psicológico e espiritual destes, garantindo-lhes dignidade, respeito, alimentação, educação, lazer e afeto.

Outro princípio que merece destaque é o da comunhão plena de vida. Com previsão no artigo 1.511 do Código Civil, é baseado no afeto entre cônjuges ou companheiros, e prioriza a boa convivência familiar como fundamento da vida conjugal. O princípio têm fornecido margens para a criação de novos modelos de família, onde os laços de afetividade predominam sobre os elementos meramente formais.

Nas lições de Carlos Roberto Gonçalves (2016, p. 25):

O reconhecimento da união estável como entidade familiar, instituído pela Constituição de 1988 no artigo 226, $\S 3^{\circ}$, retrotrascrito, e sua regulamentação pelo novo Código Civil possibilita essa opção aos casais que pretendem estabelecer uma comunhão de vida baseada no relacionamento afetivo. A aludida Carta Magna alargou o conceito de família, passando a integrá-lo nas relações monoparentais, de um pai com seus filhos. Esse redimensionamento, calcado na realidade que se impôs, acabou afastando da ideia de família o pressuposto de casamento. Para sua configuração, deixou-se de exigir a necessidade de existência de um par, o que, consequentemente, subtraiu de sua finalidade a proliferação.

Finalmente, o princípio do respeito da dignidade da pessoa humana, disposto no artigo $1^{\circ}$, III, da Constituição Federal, é base para todos os outros princípios, e impõe o respeito aos direitos fundamentais, com a finalidade de garantir aos membros da comunidade familiar, a realização e o pleno desenvolvimento, principalmente da criança e do adolescente (artigo 227, da Constituição Federal).

\section{Da responsabilidade civil e sua}

Para a nossa cultura ocidental, toda reflexão, por mais rápida que seja, sobre origens históricas de um instituto, acaba se deparando com o Direito Romano como ponto de partida. Não sendo diferente com a responsabilidade civil.

Nos primórdios, pairava sobre o instituto a concepção de vingança privada, em que os homens faziam justiça pelas próprias mãos, valiam-se da pena de Talião, ou seja, da reparação do mal pelo mal, consubstanciada na máxima "olho por olho, dente por dente". Havia a intervenção do Estado apenas para decretar como e quando a vítima teria o seu direito de retaliação, retribuindo ao lesante dano idêntico ao que experimentou. A referida pena encontra traços na Lei das XII Tábuas. 
A responsabilidade era objetiva, não dependia de culpa, manifestando-se apenas como uma reação do lesado contra a causa aparente do dano.

\section{Como observa Pablo Stolze Gagliano (2015, p. 54)}

Há, porém, na própria lei mencionada, perspectivas da evolução do instituto, ao conceber a possibilidade de composição entre a vítima e o ofensor, evitando-se a aplicação da pena de Talião. Assim, em vez de impor que o autor de um dano a um membro do corpo sofra a mesma quebra, por força de uma solução transacional, a vítima receberia, a seu critério e a título de poena, uma importância em dinheiro ou outros bens.

Um símbolo importante na evolução histórica da responsabilidade civil se deu com a edição da Lex Aquilia, que deu nome à nova designação da responsabilidade civil extracontratual, não se limitando a especificar melhor os atos ilícitos, mas substituindo as penas fixas, editadas por certas leis anteriores, pela reparação pecuniária do dano causado.

A Lei Aquília introduziu o damnum injuria datum (dano produzido pela injúria), consistente na destruição ou deterioração de bem alheio, sem justificativa legal, por dolo ou culpa, atingindo coisa corpórea ou incorpórea.

Na Idade Média, com a estruturação da ideia de dolo e de culpa, distinguiu-se a responsabilidade civil da pena.

O código civil brasileiro de 1916 aderiu à teoria subjetiva, ou seja, tanto o dolo quanto a culpa do agente deveriam ser comprovados para que houvesse possibilidade de reparação. Mas, com a evolução da sociedade, das atividades industriais, o desenvolvimento tecnológico, diversas teorias até então adotadas tiveram de ser incrementadas ou substituídas.

No código civil de 2002 a teoria objetiva ganhou lugar no ordenamento, com a introdução da teoria do risco. Destarte, a responsabilidade civil evoluiu em relação ao seu fundamento, baseando-se o dever de reparação não só na culpa, hipótese em que será subjetiva, como também no risco, caso em que passará a ser objetiva, ampliando-se a indenização de danos sem a existência de culpa.

Depreende-se da redação do parágrafo único do artigo 927 do Código Civil de 2002 que, "Haverá obrigação de reparar o dano, independentemente de culpa, nos casos especificados em lei, ou quando a atividade normalmente desenvolvida pelo autor do dano implicar, por sua natureza, risco para os direitos de outrem". 
Deste modo, o critério para aplicação da responsabilidade civil deixou de ser baseado apenas na culpa, podendo ser encontrado também no próprio fato da coisa e na execução de atividades perigosas, que aumentam o risco de dano, exigindo-se somente a prova do nexo causal entre a conduta e o dano.

\section{IV.1. Conceito}

A palavra responsabilidade é proveniente do verbo latino respondere, quer dizer obrigação que alguém tem de assumir as consequências jurídicas de suas ações, contendo, ainda, uma origem latina de spondeo, método pelo qual se vinculava no Direito Romano, o devedor nos contratos verbais.

Sempre que alguém sofre violação de sua honra ou patrimônio, o agente causador dessa situação possui o dever de repará-lo, a fim de que se tenha o equilíbrio das relações e que o lesado não fique no prejuízo.

Para Maria Helena Diniz (2014, p. 40)

A responsabilidade civil é a aplicação de medidas que obriguem uma pessoa a reparar dano moral ou patrimonial causado a terceiros, em razão de atos por ela mesma praticado, por pessoa por quem ela responde, por alguma coisa a ela pertencente ou de simples imposição legal.

A responsabilidade civil define-se pela obrigação de ressarcir o dano, cominada a todo aquele que, por ação ou omissão voluntária, ofender direito ou causar prejuízo a outrem. Percebe-se, portanto, que toda atividade humana pode acarretar o deve de indenizar.

\section{IV.2. Espécies de responsabilidade civil}

Movida, a princípio, pelo desejo de vingança privada (autotutela), a responsabilidade civil evoluiu para a categoria de punição pecuniária ao dano provocado. Havendo uma coletividade ou manifestação da atividade humana, estará presente a responsabilidade civil. Entretanto, como expõe a doutrina dominante no assunto, a responsabilidade civil pode desenvolver-se através de diversas espécies, formas, tipos e aspectos.

\section{IV.2.1. Responsabilidade contratual e extracontratual}

Para entender a diferença entre as duas espécies, é mister identificar se o ato danoso resultou de uma obrigação preexistente, isto é, decorrente de uma relação contratual, ou de uma obrigação estabelecida pela própria lei, pois no primeiro 
caso diz-se que a responsabilidade é contratual, e no segundo, extracontratual ou aquiliana.

Na responsabilidade extracontratual, aplica-se o disposto no artigo 186 do Código Civil, ficando o causador do dano obrigado a reparar o prejuízo que causar a outrem por dolo ou culpa. Não existe nenhum vínculo jurídico entre o agente e a vítima, mas para a caracterização da responsabilidade, faz-se necessário que a culpa do primeiro seja comprovada por aquele que suportou o dano.

De forma contrária, na responsabilidade contratual, prevista no Código Civil através dos artigos 389 e s. e 395 e s., é imprescindível que a vítima e o autor possuam vínculo jurídico decorrente de uma obrigação anteriormente assumida por eles, sendo a culpa contratual a violação do dever de adimplir. Em regra, a culpa é presumida, cabendo à vítima comprovar, somente, que a obrigação não foi adimplida, ficando o agente incumbido de demonstrar que não agiu com culpa.

Na precisa lição de Sérgio Cavalieri Filho (2007, p. 15):

Tanto na responsabilidade extracontratual como na contratual há a violação de um dever jurídico preexistente. A distinção está na sede desse dever. Haverá responsabilidade contratual quando o dever jurídico violado (inadimplemento ou ilícito contratual) estiver previsto no contrato. A norma convencional já define o comportamento dos contratantes e o dever específico a cuja observância ficam adstritos (...). Haverá, por seu turno, responsabilidade extracontratual se o dever jurídico violado não estiver previsto no contrato, mas sim na lei ou na ordem jurídica.

\section{IV.2.2. Responsabilidade subjetiva e objetiva}

Encontra respaldo em nosso ordenamento jurídico, a responsabilidade civil subjetiva e a objetiva. A responsabilidade civil subjetiva trata-se de dano causado a alguém em detrimento de conduta dolosa ou culposa, configurada quando o lesante atuar com negligência ou imprudência, também denominada de teoria da culpa. Nesta modalidade de responsabilidade, a prova da culpa é requisito necessário para o dano indenizável.

De outro lado, a responsabilidade civil objetiva ou teoria do risco, impõe a certas pessoas, em determinadas situações, o dever de reparar o dano, independente de prova da culpa, exigindo-se somente o nexo de causalidade e o dano. Cuida-se de uma responsabilidade indireta, em que a culpa é presumida, em razão do dever geral de vigilância a que o réu está obrigado. 
Assim, a responsabilidade civil objetiva, é regra geral trazida do código anterior, antes prevista através do artigo 159 do Código Civil de 1916, localizada atualmente no artigo 186 do Código Civil de 2002.

Em segundo plano temos a responsabilidade civil objetiva, identificada especialmente em função da atividade de risco desenvolvida pelo autor do dano, com determinação, como já dito em tópico anterior, no artigo 927, parágrafo único do mesmo diploma legal.

\section{IV.3. Elementos da responsabilidade civil}

É imprescindível no campo da responsabilidade civil, que se faça, ao menos por linhas gerais, uma breve explicação dos elementos básicos que a integram. Esses pressupostos dizem respeito tanto à responsabilidade civil contratual, quanto à aquiliana, apesar de se distinguirem por características peculiares.

Em consulta ao artigo 186 do Código Civil, alicerce primordial da responsabilidade civil, e consagrador do princípio de que "a ninguém é dado causar prejuízo a outrem" (neminemlaedere), temos que

Artigo 186- Aquele que, por ação ou omissão voluntária, negligência ou imprudência, violar direito e causar dano a outrem, ainda que exclusivamente moral, comete ato ilícito.

Extrai-se do referido dispositivo os seguintes elementos ou pressupostos da responsabilidade civil: conduta (positiva ou negativa), culpa ou dolo do agente, dano ou prejuízo e o nexo de causalidade.

A lei faz referência a qualquer pessoa que, por uma ação ou omissão, causa dano a outrem. A responsabilidade pode emanar de ato próprio, de terceiro que esteja sob a guarda do agente, ou de danos provocados por animais ou coisas que a ele pertençam, e nesse último caso, independe da prova de culpa.

O dolo pode ser observado logo no início do artigo supra transcrito, com a expressão "ação ou omissão voluntária", enquanto, a culpa, com o termo "negligência ou imprudência".

Consiste o dolo na conduta consciente, voluntária e intencional de alguém que, pratica ou deixa de praticar uma ação, objetivando um resultado ilícito ou causar dano a outrem. À medida que, na culpa, o agente possui a vontade de praticar o ato lícito, em conformidade com as normas, mas por descuido causa um dano, que apesar de previsível, não era o desejado. 
Assim, apesar de ambos partirem de uma conduta voluntária, o dolo tem caráter ilícito, com a finalidade de violar a lei e causar dano. De forma que a culpa, inicia-se com uma ação lícita, porém, sem a intenção do agente, atinge um resultado ilícito.

Como visto, na teoria subjetiva, para que a vítima obtenha a reparação do dano, é fundamental que ela prove o dolo ou a culpa do causador. Todavia, como essa prova muitas vezes é difícil de ser obtida, admite-se no direito brasileiro que, em hipóteses específicas possa ser aplicada a responsabilidade objetiva, isto é, independente de prova da existência da culpa.

Salienta-se que mesmo nos casos em que haja culpa ou dolo na conduta praticada pelo infrator, se não ficar verificado o dano causado a outrem, não persistirá o dever de indenizar.

Neste diapasão, se não houver prova do dano, ninguém poderá ser responsabilizado civilmente. $\mathrm{O}$ dano pode ser material quando a vítima efetivamente sofrer prejuízo financeiro, causando diminuição de seu patrimônio. Esse dano pode ser de duas naturezas: emergente, na hipótese do lesado ter, de fato, sofrido uma perda, e lucro cessante, no caso em que a vítima razoavelmente deixa de ganhar, ou o dano poderá ser moral, quando ocorrer a agressão à dignidade pessoal de alguém, lesionando a sua honra.

O artigo 186 do Código do Civil traz a expressão "violar direito e causar dano a outrem", inferindo-se que, a obrigação de indenizar somente será sucedida quando existir violação de direito e dano, simultaneamente.

O último elemento para configuração da responsabilidade é o nexo de causalidade, expresso no verbo "causar". É o liame une a conduta do infrator ao dano. Ainda na responsabilidade objetiva, que há a dispensa da culpa, não haverá a dispensa do nexo causal. Sem a relação entre a conduta praticada pelo agente e o dano causado, não haverá o dever de indenizar.

De acordo com Flávio Tartuce (2015, p. 372), "o nexo de causalidade ou o nexo causal é o elemento imaterial ou virtual da responsabilidade civil, constituindo a relação de causa e efeito entre a conduta culposa ou o risco criado e o dano suportado por alguém".

No entanto, há situações excludentes do nexo causal, pois o limitam ou o interrompem, como por exemplo, o caso fortuito, a força maior e o dano ocorrente por culpa exclusiva da vítima. 


\section{Da responsabilidade civil pelo abandono afetivo}

Diante da evolução do Direito de Família surge uma nova modalidade de indenização por dano moral, que vem sendo reconhecida gradualmente pelos Tribunais Brasileiros, tratando a Responsabilidade Civil por abandono afetivo parental como um direito subjetivo. Portanto, será analisado adiante como a falta de afeto prejudica as relações familiares e os sentimentos que cria no filho abandonado.

\section{V.1. A proteção da criança e do adolescente}

Certamente as crianças e os adolescentes são o futuro de uma nação, mas nem sempre foi compreendido dessa forma. No Brasil o caminho percorrido pelo direito infanto-juvenil foi de grande transição. Em primeiro momento havia a doutrina da situação irregular, em que eram acolhidos apenas os menores em situação irregular, ou seja, aqueles que não tinham qualquer assistência ou haviam violado o ordenamento jurídico. O último código de menores (Lei 6.697/79), revogado pelo atual Estatuto da Criança e do Adolescente, em seu artigo $2^{\circ}$ delineava o menor em situação irregular como sendo aquele

Artigo $2^{\circ}$ : Para os efeitos deste Código, considera-se em situação irregular o menor:

I - Privado de condições essenciais à sua subsistência, saúde, e instrução obrigatória, ainda que eventualmente em razão de: a) falta, ação ou omissão dos pais ou responsável; b) manifesta impossibilidade dos pais ou responsável para provê-las; II - Vítima de maus tratos ou castigos imoderados impostos pelos pais ou responsável; III - Em perigo moral, devido a: a) encontrar-se, de modo habitual, em ambiente contrário aos bons costumes; b) exploração em atividade contrária aos bons costumes; IV - Privado de representação ou assistência legal, pela falta eventual dos pais ou responsável; $\mathrm{V}$ - Com desvio de conduta, em virtude de grave inadaptação familiar ou comunitária, VI - autor de infração penal.

O mencionado código vigorou por 21 anos até ser revogado pelo atual Estatuto da Criança e do Adolescente (Lei 8.069 de 13 de julho de 1990), que hoje faz parte de um segundo momento no âmbito da proteção da criança e do adolescente, a doutrina da situação integral. Anunciada através da Constituição de 1988, no artigo 227 garante prioridade absoluta ao menor, sendo esta prioridade de responsabilidade da família, da sociedade e do Estado, sob pena de responderem pelos danos causados.

O ECA tem por objetivo principal a proteção integral da criança de até 12 anos de idade, e do adolescente entre 12 e 18 anos, assegurando-lhes todos os direitos fundamentais inerentes à pessoa humana. 
O artigo 19 do Estatuto da Criança e do Adolescente juntamente com o artigo 227 da Constituição Federal, assegura ao infante a convivência familiar, dispondo que toda criança e adolescente possui o direito de ser criado e educado no seio de uma família, em ambiente que garanta seu desenvolvimento integral. A inobservância a esse dever viola a dignidade, e pode causar danos irreparáveis na formação da personalidade.

A família é base cultural de uma sociedade, e cada membro possui um lugar, uma função, ainda que não haja o vínculo biológico, o que importa é pertencer ao seu cerne, é estar naquele lugar onde seja possível integrar sentimentos, esperanças, valores, e se sentir, em decorrência disso, no caminho da realização de seu projeto de felicidade.

\section{V.2. Os deveres dos pais para com os filhos}

Os deveres de um pai em relação ao filho não surgem do reconhecimento civil ou judicial da paternidade, pelo contrário, antecedem a isso, resultam da condição natural do homem enquanto agente na concepção daquele ser. A obrigação de assistência é inerente tanto à relação biológica quanto a não biológica, sendo que este dever não se resume aos alimentos, fonte de sobrevivência, mas, entre outros, também ao afeto, fonte de construção.

No direito Brasileiro atribui-se aos pais diversos deveres para com os seus filhos. Pelo artigo 22 do ECA tem-se quem é dever dos pais o sustento, a guarda e a educação dos filhos. O sustento refere-se a aspectos materiais, ou seja, despesas com a sobrevivência, saúde, alimentos, escola, cultura, lazer e educação dos filhos. A guarda tem um propósito amplo de direito-dever de convivência familiar, reputada como prioridade absoluta da criança. Ainda que pais e filhos residam em moradias diferentes, essa condição não cessa o direito à convivência familiar, e por esse motivo que o atual Código Civil garante aos pais o direito de guarda, companhia e visita dos filhos.

Nos ensinamentos de Carlos Roberto Gonçalves (2016, p. 288):

Mesmo o cônjuge declarado culpado na ação de separação litigiosa ajuizada antes da EC n. 66/2010, e que não ostentava melhores condições para exercer a guarda dos filhos menores, tem o direito de visita-los (...). Tal direito, no entanto, pode ser restringido e até suprimido temporariamente, em situações excepcionais, quando as visitas estiverem sendo comprovadamente nociva aos filhos.

Conforme prevê o artigo 33 do Estatuto da Criança e do Adolescente, a guarda obriga à prestação de assistência material, moral e educacional ao infante. 
Assim, enquanto titulares do poder familiar, os pais devem prestar aos filhos a educação necessária à sua formação, e aqui se fala em educação no sentido amplo, isto é, inclui a cultura e as várias dimensões em que ela se dá no progressivo desenvolvimento da criança.

Nos dizeres de Paulo Lôbo (2011, p. 147):

O descumprimento desse dever, em face dos filhos, acarreta várias consequências: condenação a pagamento de alimentos, substituição da guarda ou até mesmo a perda do poder familiar, e ainda a responsabilidade civil por danos morais em virtude de violação aos direitos da personalidade que se consolidam durante o período de formação da criança e do adolescente.

\section{V.3. Do abandono afetivo e suas conseqüiências}

A cada dia mais, as famílias passam a se basear na afetividade, solidariedade e na união, deixando de lado o aspecto biológico ligado ao sangue, que anteriormente definia o conceito de família. Hoje, inclusive, se houver a perda do afeto no meio familiar, os cônjuges ou companheiros podem optar pelo rompimento do vínculo, sem a exigência do elemento culpa por parte de um deles.

Compreende-se que o afeto ganhou valorização na sociedade, e por ser o direito uma ciência que regula as relações sociais, tornou-se um valor jurídico, sendo possível verificar na prática diversas normas jurídicas nesse sentido, além de influenciar nas decisões jurisdicionais no âmbito familiar.

Ao contrário do que muitos pensam o abandono afetivo não significa a falta de amor, haja vista que o amor não é tutelado pelo direito, ninguém pode ser obrigado a amar ou a manter um relacionamento afetivo. $\mathrm{O}$ abandono ultrapassa $\mathrm{o}$ simples desinteresse, ele acarreta feridas na personalidade de um filho, gerando sentimentos de rejeição, vexame, humilhação, baixa autoestima, dentre outros inúmeros sintomas.

Apesar de a existência de pais que não participam do crescimento dos filhos seja coisa antiga, a tese do abandono afetivo é relativamente atual, e tem ocupado cada vez mais espaço no mundo jurídico, devido a maior proteção da criança e do adolescente por entidades oficiais e particulares que se dedicam a tal ofício.

No dia nove de setembro do ano de 2015, foi aprovado pela Comissão de Direitos Humanos, o Projeto de Lei 700/2007. A proposta foi realizada pelo senador Marcelo Crivella, do PRB do Rio de Janeiro, possuindo como objetivo a modificação do 
Estatuto da Criança e do Adolescente, a fim de caracterizar o abandono afetivo por parte do pai ou da mãe como um ilícito civil e penal, passível de reparação.

Crivella sustenta o projeto com a seguinte indagação: "Pode o pai ausente - ou a mãe omissa - atender aos desejos de proximidade, de segurança e de agregação familiar reclamados pelos jovens no momento mais delicado de sua formação?". O autor da proposta cita o sexto princípio da Declaração dos Direitos da Criança, de 1990, que determina que "para o desenvolvimento completo e harmonioso de sua personalidade, a criança precisa de amor e compreensão. Criar-se-á, sempre que possível, aos cuidados e sob a responsabilidade dos pais e, em qualquer hipótese, num ambiente de afeto e de segurança moral e material (...)". Para ele, a Lei não tem a finalidade de modificar a consciência dos genitores, mas sim evitar e resolver os casos inadmissíveis de negligência para com a prole.

Portanto, o descumprimento do dever de cuidado, companhia e guarda dos filhos é caminho para o abandono afetivo. Os pais tem o dever de participar da formação dos filhos, guiá-los nas situações mais importantes, demonstrar-lhes solidariedade e assistência nos momentos de sofrimento e, sempre que possível, se fazer presente na vida do infante.

Há tempos atrás, essas condutas eram tidas apenas como prerrogativas dos pais, não representavam uma obrigação, pois caso não fossem exercidas, não passariam da alçada da consciência dos genitores. No entanto, com o progresso da responsabilidade civil, antes limitada apenas à esfera patrimonial e hoje compreendida também pelo prejuízo extrapatrimonial, bem como pela introdução da doutrina da situação integral na Constituição de 1988 e no Estatuto da Criança e do Adolescente de 1990, a visitação, companhia e guarda, passaram a ser tidas como direito fundamental dos infantes.

A assistência psíquica, moral, e afetiva é dever dos pais, e sua desobediência, seja por um ou ambos os genitores, gera consequências psicológicas negativas na formação de uma criança, visto que elas não possuem capacidade para compreender da mesma forma que os adultos, o porquê da desmotivada ausência de um dos pais.

\section{V.4. Finalidades da aplicação da responsabilidade civil ao abandono afetivo}

O descumprimento à convivência familiar e à necessidade de afeto causa danos à dignidade humana da criança que passa por uma fase de formação, e por isso, passível de indenização.

Para que seja possível a configuração da responsabilidade civil pelo abandono afetivo é necessário que a conduta seja antijurídica, que neste caso seria a não 
https://doi.org/10.24215/25916386e002

observância pelo genitor do dever de cuidar e proteger a prole tanto no aspecto material como no afetivo e psicológico; o dano causado ao filho pelos fatos praticados pelo agente, sendo necessária a comprovação de que a criança efetivamente sofreu danos em sua dignidade e personalidade; que esteja presente o nexo de causalidade, ou seja, que os danos sofridos tenham resultado da conduta do agente.

Presentes os pressupostos acima citados, restará ao causador dos danos à obrigação de reparação, por inteligência do artigo 186 e 927 do Código Civil.

Certamente, um relacionamento baseado na coerção e na ameaça de penalização pecuniária não é o melhor caminho para se construir um vínculo, melhor que indenizar seria se pai e filho, voluntariamente, se relacionassem. No entanto, muitos pais não possuem essa consciência, não enxergam a importância de conviver e dar afeto à sua prole.

No entendimento de Maria Berenice (2015, p. 97):

A omissão do genitor em cumprir os encargos decorrentes do poder familiar, deixando de atender ao dever de ter o filho em sua companhia, produz danos emocionais merecedores de reparação. Se lhe faltar esta referência, o filho estará sendo prejudicado, talvez de forma permanente, para o resto de sua vida. Assim, a ausência da figura do pai desestrutura os filhos, tira-lhes o sentido da vida e debita-lhes a vontade de assumir um projeto de vida. Tornam-se pessoas inseguras, infelizes. Tal comprovação, facilitada pela interdisciplinaridade, tem levado ao reconhecimento da obrigação indenizatória por abandono afetivo. Ainda que a falta de afetividade não seja indenizável, o reconhecimento da existência do dano psicológico deve servir, no mínimo, para gerar o comprometimento do pai com o pleno e sadio desenvolvimento do filho. Não se trata de impor valor ao amor, mas reconhecer que $\mathrm{o}$ afeto é um bem que tem valor.

Portanto, o distanciamento entre pais e filhos acarreta sequelas de ordem emocional, que podem desenvolver problemas físicos e comprometer a formação e desenvolvimento de sua personalidade. $\mathrm{O}$ sentimento de dor e abandono pode refletir para o resto de sua vida.

Indubitavelmente, a família é o suporte estrutural do desenvolvimento cognitivo social e emocional da transmissão dos conceitos da identidade do indivíduo, e a indenização, nessas situações, tem a finalidade de punir o agente causador do dano, reparando de forma material a lesão psíquica sofrida pela criança. 
Destarte, podemos destacar como principais finalidades da aplicação da responsabilidade civil pelo abandono afetivo, a prevenção de que condutas iguais a estas continuem acontecendo, a compensação dos prejuízos sofridos pela vítima e o desestímulo para que outros pais pratiquem a referida conduta.

\section{V.4.1. Os danos morais decorrentes da responsabilização}

Proteger a família, nos dias atuais, é o mesmo que proteger a dignidade da pessoa humana. Partindo-se do princípio de que, qualquer ato que lese a outrem é passível de indenização.

O dano moral foi introduzido na constituição Federal de 1988 para proteger o mais importante de todos os direitos, a dignidade da pessoa humana. Possui o propósito de compensar um sentimento de dor, humilhação, assim como sensações de constrangedoras ou vexatórias.

Geralmente o que os humilha, constrange, abala nossa honra, é exatamente o que atenta contra nossa dignidade. Diante disso, desde que provada à ocorrência efetiva do dano psicológico, e sendo possível de ressarcido com um valor pecuniário, a vítima deverá ser indenizada.

O que deverá ser levado em consideração em cada caso é o grau de culpa, a extensão do dano, a situação do agente e a intensidade do sofrimento causado á vítima, de modo que o ressarcimento possa atender ao caráter punitivo e compensatório.

Por meio de uma fórmula abstrata, caberá ao magistrado a redução da angústia à pecúnia, a fim de alcançar a punição necessária. É deste modo que o amor acaba ganhado um valor, que irá variar de acordo com cada sentença.

Por isso é que os danos morais são a resposta certa para proteger o afeto, considerado na atualidade como pressuposto valorativo que proporciona ao ser humano a energia vital para suas relações diárias.

\section{V.5. 0 posicionamento dos Tribunais brasileiros quanto à possibilidade de indenização}

Os tribunais do país vêm se comportando de forma diversificada, as opiniões são muito divergentes. Duas correntes travam uma árdua disputa nesse campo: de um lado, o posicionamento de que o abandono afetivo encontra punição dentro do próprio direito de família, por meio da destituição do poder familiar, e que a conduta praticada pelo agente não gera ato ilícito, portanto, inexistente o dever de 
indenizar. Essa posição acredita que a fixação de indenização nesses casos, levaria à monetarização do amor, o que é incabível, pois estariam obrigando alguém a amar.

Nesse sentido, temos a recente decisão do Tribunal de Justiça de Minas Gerais:

EMENTA: APELAÇÃO CÍVEL. AÇ̃̃O DE INDENIZAÇÃO POR DANOS MORAIS. DESCUMPRIMENTO DO DEVER OBJETIVO DE CUIDADO. ILICITUDE. INEXISTÊNCIA. SENTENÇA REFORMADA.

- A indenização por dano moral pressupõe a prática de um ilícito, o que não se verifica pelo chamado "abandono afetivo", insuscetível de correspondente compensação pecuniária. (TJMG - Apelação Cível 1.0024.13.180528-5/001, Relator (a): Des.(a) José Marcos Vieira, 16a CÂMARA CÍVEL, julgamento em 15/12/2016, publicação da súmula em 26/01/2017).

No julgamento acima, o relator articulou que independente da posição adotada, o tema deve ser tratado com imensa cautela, sob pena de vulgarização da relevância da família perante a sociedade.

No Superior Tribunal de Justiça:

RECURSO ESPECIAL. CIVIL. DIREITO DE FAMÍLIA. AÇÃO DE INDENIZAÇÃO. ABANDONO AFETIVO. NÃO OCORRÊNCIA. ATO ILÍCITO. NÃO CONFIGURAÇÃO. ART. 186 DO CÓDIGO CIVIL. AUSÊNCIA DE DEMONSTRAÇÃO DA CONFIGURAÇÃO DO NEXO CAUSAL. SÚMULA No 7/STJ. INCIDÊNCIA. PACTA CORVINA. VENIRE CONTRA FACTUM PROPRIUM. VEDAÇÃO. AUSÊNCIA DE PREQUESTIONAMENTO. DISSÍDIO JURISPRUDENCIAL. NÃO CARACTERIZADO. MATÉRIA CONSTITUCIONAL. 1. A possibilidade de compensação pecuniária a título de danos morais e materiais por abandono afetivo exige detalhada demonstração do ilícito civil (artigo 186 do Código Civil) cujas especificidades ultrapassem, sobremaneira, o mero dissabor, para que os sentimentos não sejam mercantilizados e para que não se fomente a propositura de ações judiciais motivadas unicamente pelo interesse econômico-financeiro. 2. Em regra, ao pai pode ser imposto o dever de registrar e sustentar financeiramente eventual prole, por meio da ação de alimentos combinada com investigação de paternidade, desde que demonstrada a necessidade concreta do auxílio material. 3. É insindicável, nesta instância especial, revolver o nexo causal entre o suposto abandono afetivo e o alegado dano ante o óbice da Súmula nº 7/STJ. 4. $\mathrm{O}$ ordenamento pátrio veda o pacta corvina e o venire contra factumproprium. 5. Recurso especial parcialmente conhecido, e nessa parte, 
não provido (REsp 1493125/SP, Rel. Ministro RICARDO VILLAS BÔAS CUEVA, TERCEIRA TURMA, julgado em 23/02/2016, DJe 01/03/2016).

Segundo o ministro relator, Ricardo Villas BôasCueva, a inexistência de afeto no ambiente familiar, em regra, não caracteriza dano a ser ressarcido por meio de indenização pecuniária, haja vista que o afeto é sentimento imensurável materialmente, que ultrapassa a tutela jurídica.

De outro lado, mesmo que paulatinamente, a jurisprudência tem formado posicionamentos favoráveis à indenização pelo abandono afetivo. Manifesta-se que, havendo comprovação dos prejuízos sofridos pela vítima, esta deve ser ressarcida, baseando-se primordialmente no princípio constitucional da dignidade da pessoa humana.

Outra decisão de grande repercussão foi a da ministra Nancy Andrighi, do Superior Tribunal de Justiça:

CIVIL E PROCESSUAL CIVIL. FAMÍLIA. ABANDONO AFETIVO. COMPENSAÇÃO POR DANO MORAL. POSSIBILIDADE. 1. Inexistem restrições legais à aplicação das regras concernentes à responsabilidade civil e o consequente dever de indenizar/compensar no Direito de Família. 2. O cuidado como valor jurídico objetivo está incorporado no ordenamento jurídico brasileiro não com essa expressão, mas com locuções e termos que manifestam suas diversas desinências, como se observa do artigo 227 da CF/88. 3. Comprovar que a imposição legal de cuidar da prole foi descumprida implica em se reconhecer a ocorrência de ilicitude civil, sob a forma de omissão. Isso porque o non facere, que atinge um bem juridicamente tutelado, leia-se, o necessário dever de criação, educação e companhia - de cuidado - importa em vulneração da imposição legal, exsurgindo, daí, a possibilidade de se pleitear compensação por danos morais por abandono psicológico. 4. Apesar das inúmeras hipóteses que minimizam a possibilidade de pleno cuidado de um dos genitores em relação à sua prole, existe um núcleo mínimo de cuidados parentais que, para além do mero cumprimento da lei, garantam aos filhos, ao menos quanto à afetividade, condições para uma adequada formação psicológica e inserção social. (...) Recurso especial parcialmente provido (REsp 1159242/SP, Rel. Ministra NANCY ANDRIGHI, TERCEIRA TURMA, julgado em 24/04/2012, DJe 10/05/2012).

A relatora, em fundamentação ao seu voto, descreveu:

Vê-se hoje nas normas constitucionais a máxima amplitude possível e, em paralelo, a cristalização do entendimento, no âmbito científico, do 
que já era empiricamente percebido: o cuidado é fundamental para a formação do menor e do adolescente; ganha o debate contornos mais técnicos, pois não se discute mais a mensuração do intangível - o amor - mas, sim, a verificação do cumprimento, descumprimento, ou parcial cumprimento, de uma obrigação legal: cuidar. Negar ao cuidado o status de obrigação legal importa na vulneração da membrana constitucional de proteção ao menor e adolescente, cristalizada, na parte final do dispositivo citado: '(...) além de colocá-los a salvo de toda a forma de negligência (...)'. Alçando-se, no entanto, o cuidado à categoria de obrigação legal supera-se o grande empeço sempre declinado quando se discute o abandono afetivo - a impossibilidade de se obrigar a amar. Aqui não se fala ou se discute o amar e, sim, a imposição biológica e legal de cuidar, que é dever jurídico, corolário da liberdade das pessoas de gerarem ou adotarem filhos. $\mathrm{O}$ amor diz respeito à motivação, questão que refoge os lindes legais, situando-se, pela sua subjetividade e impossibilidade de precisa materialização, no universo meta-jurídico da filosofia, da psicologia ou da religião. O cuidado, distintamente, é tisnado por elementos objetivos, distinguindo-se do amar pela possibilidade de verificação e comprovação de seu cumprimento, que exsurge da avaliação de ações concretas: presença; contatos, mesmo que não presenciais; ações voluntárias em favor da prole; comparações entre o tratamento dado aos demais filhos - quando existirem -, entre outras fórmulas possíveis que serão trazidas à apreciação do julgador, pelas partes. Em suma, amar é faculdade, cuidar é dever.

Portanto, segundo a fundamentação da ministra, a comprovação do descumprimento do dever de cuidado, implica a ocorrência de ilícito civil, sob a forma de omissão. O sentimento de desprezo sentido pelo filho em decorrência da conduta omissiva traduz motivo suficiente à compensação.

É certo ser impossível obrigar alguém a amar, mas faz-se necessário compreender que o reflexo do desamor, do abandono, da ausência de um dos genitores na vida pessoal e psicológica do filho, pode vir a acarretar uma obrigação de ressarcir os prejuízos causados por essas condutas.

\section{Conclusão}

Com base no presente estudo, compreende-se que o afeto tem se tornado o agente agregador da família. A procriação deve ser subordinada a uma vivência profundamente amorosa e consciente do casal, pois, se não existe amor verdadeiro, não deve ser gerado um ser. 
Com base no princípio na dignidade da pessoa humana, reconhecido na Constituição Federal de 1988, considerou-se possível a condenação de pais negligentes ao pagamento de indenização, com a finalidade de estabelecer responsabilidades decorrentes da ação voluntária de se conceber uma criança, ainda que o ato seja advindo de uma situação não planejada ou até mesmo nos casos em que não há relação matrimonial entre os genitores.

É inaceitável a ideia de abandonar a prole à deriva pelo mundo, deixando-os à sua própria sorte e impedindo-os de receber os cuidados necessários a um desenvolvimento sadio, garantido pelo nosso ordenamento jurídico. Alguns cargos, como o de pai e mãe, apesar de insubstituíveis e indelegáveis, podem se tornar apenas rótulos, quando não são cumpridos os papeis a eles impostos por meio legal.

Foi demonstrado que há decisões, proferidas por tribunais com base no argumento de que não se pode impor a obrigação de amar. Não há dúvidas quanto à impossibilidade de tal imposição. No entanto, alguns julgadores se esquecem de que o amor é um sentimento aprendido. Ninguém nasce sabendo a amar os pais, os tios ou os irmãos, mas aprendem esse sentimento com o tempo, isto é, com o convívio.

Em decorrência disso, é que a ausência de um pai é tão traiçoeira na vida de um filho, haja vista que este foi privado de aprender a amar. Assim, tem-se reconhecido a possibilidade de imputar uma pena como reparação por essa conduta moralmente reprovável.

Com o propósito de proteger a dignidade da pessoa humana, os direitos da personalidade e da solidariedade nas relações pessoais, é que deve ser viável o reconhecimento da indenização por abandono afetivo, desde que presentes os elementos da responsabilidade civil. O tema ainda é de grande discussão em meio à doutrina e a jurisprudência, mas aos poucos vem sendo reconhecido.

No entanto, é extremamente fundamental o bom senso e a cautela na solução dos casos concretos, pois o objetivo não é transformar a questão em um meio de obtenção de vantagens, mas sim reparar as vítimas e desencorajar a prática do abandono, para que seja estabelecida gradativamente uma consciência de genitores mais responsáveis e cientes da importância do afeto e da convivência para formação da personalidade do filho.

\section{Referência}

Dias, M. B. (2015). Manual de Direito das Famílias. São Paulo-SP: Revista dos Tribunais. 
Diniz, M. H. (2014). Direito Civil Brasileiro: Direito de Família. São Paulo-SP: Saraiva.

Filho, S. (2007). Programa de Responsabilidade Civil. São Paulo-SP: Atlas.

Gagliano, P. y Filho, R. (2015). Novo curso de Direito Civil. São Paulo-SP: Saraiva.

Gonçalves, C. R. (2015). Direito Civil Brasileiro: Responsabilidade Civil. São Paulo-SP: Saraiva.

Gonçalves, C. R. (2016). Direito Civil Brasileiro: Direito de Família. São Paulo -SP: Saraiva.

Lobo, P. (2011). Direito Civil: Famílias. São Paulo-SP: Saraiva.

Pereira, C. M. (2015). Instituições de Direito Civil: Direito de Família. Rio de Janeiro-RJ: Forense.

Silva, J. A. (2012). Curso de Direito Constitucional Positivo. São Paulo-SP: Malheiros.

Venosa, S. (2012). Direito Civil: Direito de Família. São Paulo: Atlas.

\section{Legislassem}

Constituição (1988). Constituição da República Federativa do Brasil. Brasília.

Lei No 10.406. Institui o Código Civil. Diário Oficial da União. Brasília, DF.

Lei No 6.697. Institui o Código de Menores. Diário Oficial da União, Brasília DF.

Lei No 8.069. Institui o Estatuto da Criança e do Adolescente. Diário Oficial da União, Brasília DF.

Projeto de Lei 700. Modifica a Lei No 8.069, de 13 de julho de 1990 ("Estatuto da Criança e do Adolescente") para caracterizar o abandono moral como ilícito civil e penal, e dá outras providências. Recuperado de https://www25.senado.leg.br/ web/atividade/materias/-/materia/83516 [Fecha de consulta: 28/05/2017].

\section{Jurisprudência}

Apelação Cível No 1.0024.13.180528-5/001. Relator: José Marcos Vieira, Data de julgamento: 15/12/2016, 16 Câmara Cível, Data de Publicação: DJE 26/01/2017. Recuperado de http://www5.tjmg.jus.br/jurisprudencia/pesquisaPalavrasEspelhoAcordao.do? \&numeroRegistro $=1$ \&totalLinhas $=1$ \&paginaNumero $=1 \&$ linhas- 
PorPagina $=1$ \&palavras=descumprimento $\% 20$ dever $\% 20$ objetivo $\% 20$ cuidado $\% 20$ ilicitude\%20inexist\%EAncia\&pesquisarPor=ementa\&pesquisaTesauro=true\&orderByData $=1$ \&referenciaLegislativa $=$ Clique\%20na\%20lupa\%20para\%20pesquisar\%20as\%20refer\%EAncias\%20cadastradas...\&pesquisaPalavras=Pesquisar\&> [Fecha de consulta: 29/05/2017].

Recurso Especial No 1159242 SP 2009/0193701-9. Relator: Nancy Andrighi, Data de Julgamento: 24/04/2012, 3a Turma Cível, Data de publicação: DJE 10/05/2012. Recuperado de <http://s.conjur.com.br/dl/acordao-abandono-afetivo.pdf $>$ [Fecha de consulta: 30/05/2017].

Recurso Especial No 1573921 MG 2015/0071793-6. Relator: Ricardo Villas Bôas Cueva, Data de Julgamento: 23/02/2016, 3a Turma Cível, Data de Publicação: DJE 01/03/2016. Recuperado de <https://www.jusbrasil.com.br/diarios/ documentos/323069694/andamento-do-processo-n-2015-0071793-6-recurso-especial-11-04-2016-do-stj> [Fecha de consulta: 29/05/2017].

Fecha de recepción: 15-03-2019 Fecha de aceptación: 24-07-2019 